\title{
Rural Tourism in Mexico: Two Community Based Sustainable Experiences
}

\author{
Gloria Miranda*, Yolanda Massieu, Jorge Arellano \\ Mexico
}

*Corresponding Author: Gloria Miranda, Mexico

\section{INTRODUCTION}

The chapter's aim is about how some rural communities manage to preserve and use in a sustainable way their natural resources through rural sustainable tourism projects. We depart form an ecosociological approach, which means that we consider community-based management of natural resources as a sustainable choice that proposes an alternative to depredatory economic rationality. Specifically, we think that indigenous and peasant people in Mexico have an antique and profound knowledge towards Nature, that implies a respectful relationship, and this is expressed in the two experiences we describe, in spite of their conflicts. This kind of knowledge is embedded in a Nature's notion as people's patrimony and legacy, more than a way of getting increasing profits.

It is not a secret that our world suffers from a non-sustainable economic model, which has generated an increasing destruction of Nature and natural resources. Most recent economic crisis in 2008 has given birth to an even more depredatory way of using these resources, such as mining and oil extraction through fracking, among many other examples. Besides, food production has been neglected in many countries that depend from imports, and an increasing amount of land is being used to produce agrofuels. The result is that many people are starving in the world and vital natural resources, such as water, are more and more scarce every day, while depredatory new projects such as open sky mining spend great amounts of it.

In this context we expose two community based sustainable experiences in Mexico, which express clearly the difficulties to achieve this kind of tourism. Both show different relationships between conservation and so called economic development, in two different environments: The first one, The EcotouristicEjidal ${ }^{1}$ Park in San NicolásTotolapan, a community in Mexico City, which shows the challenges of preserving forests and water in one of the biggest cities in the world. The second one shows contradictions among a beach multi-racial community and a sea-turtle conservation project.

In the chapter we depart form theoretical discussion concerning eco-sociological approach, in which we discuss how sustainability as a goal faces a dominant concept of economic development and rationalitythat consider natural resources as a raw material to exploit, with no regard to environmental and social damage. Sustainability in this sense means that natural resources are not eternal and humanity has to achieve ways to live with nature and take care of these resources for the future generations' sake. It is in this contradiction where we find that peasant and indigenous human communities in Mexico (and maybe in the rest of LatinAmerica) are more suitable to endeavor sustainable tourism projects, which can allow them both reasonable profits and respect for Nature, preserving their resources. This wisdom comes both from their very antique cultures ant their colonial history.

Our first case, besides, expresses how a big and always growing city threatens permanently natural resources' existence. San NicolásTotolapan'sejidatarios have learned, with many difficulties, that preserving their forest and water is better than just selling their land in order to build houses and urban

\footnotetext{
${ }^{1}$ Ejido is a unique Mexican land's collective property, which was originated from Mexican Revolution in 1910
} 
projects. The successful ecotouristic park, which began in 1996 as a very few people in the ejido's project, with some scientists' help, and today has shown to the rest of the ejido's people that they can earn some money and not suffer of water scarcity if they preserve their forest. Nevertheless, this does not mean that the park is not permanently threatened, as some of the land's owners in the ejido are frequently tempted by investors in urban projects. Being ejido a collective land property helps to endure selling temptation, but they have to be prepared all the time to preserve their impressive forest.

Our second case is placed in a region of beautiful Pacific Ocean's beaches. In La Escobilla community (a paradise with lagoon and beach), afro-descendents, zapotecindigenous and mixed people have lived from sea-turtle eggs for many decades. An international and government sea-turtle conservation project finished with this way of life, and the project's technic personnel convinced a group of the community to start an eco-touristic cooperative, instead of selling sea-turtle eggs. This led to a division in the community, and the starting eco-touristic project has suffered even from violent attacks, such as the restaurants' intentional fire by community people who did not want the project and wished to continue collecting sea turtle's eggs. In spite of this, the group convinced of eco-tourism could take the project in their hands, and nowadays they have some bungalows and touristic activities. All this in a region, Oaxaca's coast, where in recent decades touristic private projects have expanded, led by big hotels and corporations with government's support.

We feel that our two examples provide a rich material that allows us to some moderately optimistic conclusions about the possibility of achieving community-based sustainable touristic projects in very adverse conditions.

\section{ECO-SOCIOLOGICAL APPROACH: OUR THEORETICAL POSITION}

Since 1992, when the United Nations (U.N.) Conference on Environment and Development (UNCED, the Rio Summit) took place in Rio de Janeiro, Brazil, ecological crisis has been a main issue in international forums and a concern for many civil and NG (Non-governmental) organizations. A few years prior to that, with the Our Common Future U.N. Document in 1987, the first emergency call sounded about the way in which economic growth and development of the XX Century had destroyed natural resources, in turn giving rise to a risk for the survival of future generations. The urgent need for a new type of development was accepted, and "sustainable" development was first mentioned as a new form of human survival that would not cause the destruction of our planet.

Although these two events led to "official" international concern with regard to ecological risk, the debate was not new: from the beginning of colonization, indigenous communities in Latin America and other regions in the world had undergone the deprivation of their territories and natural resources. This long historical process initiated the destruction of ecosystems due to capitalist expansion through industrial development, which reached its limits at the beginning of the XXI Century. It is not an exaggeration that total destruction of life on our planet is now possible due to this kind of development.

An intense academic and political discussion about development took place during the nineties of the last century (Escobar,1995). Originally the idea of economic development originated in post-WWII, and in the fifties and sixties of XXth Century, became commonplace in international institutions, which aided peripheral countries, implying that these latter nations should make efforts to achieve economic development, as had occurred in central countries. Some decades later, it became clear that, despite the numerous sacrifices that development had demanded from peripheral countries, goals such as the decline of poverty were far from being achieved. It is within this context that environmental concerns have become more important, and discussion on poverty associated with environmental degradation has now come to the fore, together with gender issues.

The latter means that many international funds since the nineties have been driven toward sustainable projects in rural areas, and a recognition that alleviating poverty would produce an environmental benefit has been fully accepted.

However, present world crisis has been accompanied by more questions about our way of development, because poverty and environment damage have increased, despite the international projects and funds developed precisely to solve these problems. The main question concerns changing present economic and market rationality as a way of solving this crisis.

This is not an easy goal, although some efforts in Latin America are underway to seek a new 
approach, which includes respect for the environment and for Nature. Ecuador's legislation with respect to the rights of Nature is an example. In these new proposals, which have been termed postneoliberal and denominated good living models, community-based projects in the hands of indigenous and local people, such as ecotourism, play a main role.

In our both cases we can see clearly how local and indigenous people are capable of managing their common natural resources, despite the dominating conservation tendency in the world, which prefers proposals about making biological resources inventories by scientists, more than promote local people's sustainable projects. Unfortunately, the mentioned conservation concept is the dominating one many of the funding institutions.

Ecological crisis is very closely related with power relations among countries. As we have mentioned, colonization was a first step in depriving peripheral countries of their territories and natural resources, and environmental damage commenced from the beginnings of capitalistic industrial development in the XVIII Century, becoming more acute in XX and XXI Centuries. Natural resources have always been objects of dispute, and economic rationality has led to the unmeasured exploitation of both people and these resources. These two factors are identified as "conditions for accumulation" by O'Connor (2001), and their destruction comprises the second contradiction of capitalism, following the tendency for profit rates to fall.

Now we know that this kind of development has driven us to a limit at which life on our planet could be completely destroyed. Climate change is the most recent and visible consequence, but not the only one. In present times, ecological destruction has worsened and includes new mining and hydroelectric projects, as well as the expansion of energetic and industrial agricultural projects into biological megadiverse territories, with no concern for damage both to humans and Nature. This process has been characterized as "accumulation by dispossession" (Harvey, 2004), and expresses the present way of capital growth. Accumulation by dispossession is a process that entails the destruction of nature and the degradation of ecosystems. As stated in 1976 by Lefevre, capitalism survives through space production, and this means that all of the places where resources are found, including people, are dominated and employed for the accumulation of capital. For Harvey, since the seventies, over accumulation crises have required spatiotemporal 'fixes' in order to achieve a broader reproduction of capital, and there is an internal incapacity of achieving this type of accumulation in a sustainable fashion. What Harvey terms accumulation by dispossession was employed prior with the use of primitive accumulation by Luxemburg (1915), who emphasized the dual character of capitalism in which, in some places, surplus value production takes place and capitalist rules work, while in some other regions accumulation occurs to a greater degree over non-capitalistic ways of production. This is equal to dispossession and colonization, frequently by unethical means such as theft and fraud, with the collusion of local governments. In fact, there is an interesting theoretical debate concerning accumulation by dispossession as a "new" way of capital growth, as colonization processes meant primitive ways of producing wealth, using violence to deprive local communities in order to appropriate their resources and exploiting their labor. This discussion emphasizes how in recent economic crisis context, exploiting natural resources without any concern to environmental damage produces profitable rents (Bartra, 2015).

In the original Marxist characterization of primitive accumulation, we find the following: depredatory processes, such as "the commodification and privatization of land and the forceful expulsion of peasant populations; conversion of various forms of property rights -common, collective, state, etc.into exclusive private property rights; suppression of rights to the common; commodification of labor power and the suppression of alternative, indigenous forms of production and consumption; colonial, neo-colonial and imperial processes of appropriation of assets, including natural resources; monetization of exchange and taxation, particularly of land; slave trade, and usury, the national debt, and ultimately, the credit system. The state, with its monopoly of violence and definitions of legality, plays a crucial role in both backing and promoting these processes. All of the features that Marx mentions have remained powerfully present within capitalism's historical geography. Some of them have been fine-tuned to play an even stronger role now than in the past" (Harvey, 2004: 113).

We emphasize here that dispossession means the exploitation and destruction of natural resources and territories, and the profits obtained this way do not remain in the place nor do they benefit local inhabitants. In fact, in present overaccumulation crisis capitals that cannot be invested with profit in their places of origin seek profits throughout the world, and this means their Nature's destruction. 
Novel and additional environmental depredatory forms of mining and oil and gas exploitation are the faces of accumulation by dispossession, especially in the rural areas of peripheral countries.

What Harvey calls into view is that this process has never ended and that, at times of over accumulation crisis, such as at this moment, the process increases and expands in peripheral countries to benefit the central nations, because the former encounter more difficulties in reproducing accumulation in their territories. This implies mobility of investments and populations, because over accumulation is expressed as an excess of both the central countries' labor forces and the commodities, which cannot be sold locally with profit. Thus, it is necessary to seek new markets, new productive capabilities, and new labor and natural resources in other places, in a process denominated by Harvey "spatio-temporal fixes" (Harvey, 63). If over accumulated capital cannot move, there is a risk of the devaluation of these assets in their own place. This way, capital creates a history and a landscape for its reproduction. Currently, capitalism combines a growing financial economy that is increasingly divorced from production, with an acute process of dispossession that moves capital and investments away from central countries to peripheral ones, where the latter are suffering from the destruction of both their capital and Nature, with the increase of poverty as a consequence.

All of this is happening in the middle of an acute international struggle for hegemony, in which the United States of America (U.S.) is not willing to relinquish its power, despite the expanding economic power of China. Europe is not in better competitive place off in this struggle. It appears that the new dynamic center of accumulation is Asia, but the U.S. is determined to maintain its dominion through both military and oil control strategies. This is what Harvey calls the "new imperialism", and it has strong consequences for the destiny and Nature of peripheral countries. New financial world importance includes unequal relations in which weaker countries are required to seek credit and are submitted to international organism adjustment programs (such as the International Monetary Fund [IMF]), meaning that these countries must frequently sacrifice their development aims. Of course, their natural resources are an important part of these arrangements. Complete economies have been ruined in this way, and this has led them to ask for more credit under even worse conditions, in a process where Nature is increasingly destroyed and development is increasingly more difficult. Harvey calls our attention to how accumulation by dispossession at present comprises the main form of accumulation in the world, and it is our objective to reflect on how this renders it more difficult to reach sustainability. We also want to point out the manner in which peripheral governments contribute to this process, while local social actors, frequently under adverse conditions, are building projects, such as the ones described here: EcoturistEjidal Park in Mexico City and La Escobilla Project in Oaxaca, where sustainability and fair relations among humans and between humans and nature are possible.

The latter face a world in which more and more powerful corporations are the real rulers of the world economy, and they possess great mobility in seeking as much profit as possible, without taking environmental or social damage into account. With regard to production, these firms control seeds, fertilizers, electronic products, computer programs, and pharmaceutical and oil products, among many examples. Under these conditions, more trade opening, as imposed on peripheral countries, only creates opportunities for monopolistic powers, with all of their consequences. Nearly two thirds of international trade takes place among corporations, frequently through unethical means, providing us an idea of their power. "Free trade does not mean fair trade" (Harvey, 2004:71). This briefly described international background depicts for us how the geographical expansion of capitalism promotes unequal relations among countries and peoples, meaning that environmental damage and its social consequences are worse in peripheral countries that, paradoxically, are those who possess the majority of natural resources and biodiversity in the world.

A new environmental rationality is required (Leff, 2004), together with a new way of development with respect to Nature, and not through the promotion of ecological destruction. In order to achieve this objective, we can turn to the ancestral knowledge that has survived in many indigenous and local groups. In Latin America, there are a myriad of experiences in this respect. However, we must be careful not to conceive of our indigenous and local people and their knowledge as frozen in the past, only able to bring to our present times their ancient wisdom. To the contrary, these individuals have survived through centuries and are now as modern as those of any other culture, although in many cases they certainly have acquired more knowledge about how to live from nature without destroying it. In Mexico, the majority of preserved ecosystems are the property of indigenous people, despite the 
difficulties they have encountered to survive (Boege, 2008).

Porto-Gonçalves and Betancourt (2015) characterize this process as "social reappropriation of nature", proposing it as a way to overcome the space-time dichotomy. These authors identify space-time dynamics, instead of constructing only periodical chronologies, in which nature and territories comprise the main actors and define the manner in which capital expands.

We think that this proposal can be related with accumulation by dispossession, as both statements identify the complex space-time relationship involved in the way Nature is dominated by capital and the forms that local social actors resist, proposing sustainable ways to survive in nature without destroying it. Of prime importance in these projects is knowledge, often maintained through centuries by local actors and re-fashioned into modern ways.

There is an interesting debate concerning local or traditional knowledge, mistakenly referred to as "traditional", and its relationship with natural resources and the use of biodiversity. This knowledge has frequently been despised by science despite it includes a vast collection about plants and living creatures assembled by international corporations. In this process, it is common not to warn the legitimate owners of both resources and knowledge. This implies a new mechanism of accumulation by dispossession. "The emphasis upon intellectual property rights in the WTO negotiations (the socalled TRIPS ${ }^{2}$ agreement) points to ways in which the patenting and licensing of genetic materials, seed plasmas, and all manner of other products, can now be used against whole populations whose environmental management practices have played a crucial role in the development of those materials. Biopiracy is rampant and the pillaging of the world's stockpile of genetic resources is well underway, to the benefit of a few large multinational companies. The escalating depletion of the global environmental commons (land, air, water) and proliferating habitat degradations that preclude anything but capital-intensive modes of agricultural production have likewise resulted from the wholesale commodification of nature in all its forms" (Harvey, 2004:75). There is hardly a need to insist that this new type of dispossession means even more destruction of Nature. Natural resources and biodiversity have been managed as common goods for many centuries, and this mechanism implies a new threat to both their conservation and to collective property. As stated by Ostrom (1990) some years ago, in the author's response to neoliberal criticism of the commons as depredatory of natural resources, often times collective property in the hands of local people is the best way to use and not destroy them.

So-called "traditional" or local knowledge can also be applied to ecotourism projects. Among the previously mentioned sustainable projects with international funds, ecotourism plays a main role. It began to be promoted as a way to alleviate poverty, to contribute to decreasing environmental damage in peripheral countries, and as an alternative to damages caused by massive tourism. This means that ecotourism is seen as local and sustainable. A risk discussed in the promotion of these projects is that of "folklorizing" indigenous peoples and their cultures, because they can be exposed. In the two described experiences we think that this risk can be avoided because indigenous and local people have the ecotourism project in their own hands, they follow their own rules, and they preserve their culture, biodiversity, and natural resources. Nevertheless, achieving these autonomy goals has not been easy and conflicts are frequent.

Recently in Mexico, as rural society has been neglected and a scenario of poverty and violence has been inflicted, together with an increasing migration, people who stay in the place have managed to seek for surviving options, such as ecotourism. In the case of our two experiences, we also have observed the importance of local organization against new threats, such as urbanization in Totolapan, and conservation institutions and turtles eggs' collectors in La Escobilla. Bothprojects are brieflydescribed in thenextpages.

\section{SAn Nicolástotolapan: An EJIDAlecotouristic Park In MeXico City}

Our objective in the study of this experience is to demonstrate how conservation of natural patrimonial resources using rural tourist services can be achieved in an ejido in Mexico City. We emphasize how in a context of pressure and dispute, an ecotouristic project has shown its pertinence and success. It is not only as a significant economic income how we measure this success, but also

\footnotetext{
${ }^{2}$ Agreement on Trade Related Aspects of Intellectual Property Rights, of the World Trade Organization
} 
because of its impact in sustainable ways of using the ejidatario's natural patrimony and giving environmental services to one of the biggest and always growing (and polluted) cities in the world.

Considering the depredatory way of capital development we described before, it is encouraging to see this kind of experiences. The EcotouristEjidal Park of San NicolásTotolapan has 2,304 hectares of forest, managed by 336 ejidatarios, both as a community natural protected area and an ecotouristic project. It has strategic importance, as it is part of the biological corridor that surrounds Mexico City and gives essential environment services, such as water generation and oxygen production for the city (Miranda, 2011).

The ejido has lived a history of greed and depriving of its land, and ejidatarios have been capable of resistance and creativity, shown today in their agriculture activities and their forest management, which recently has developed the ecoturistic project. The park is a leader project in Community Rural Ecotourism in Mexico and Latin America, and receives an increasing number of visitors, specially during weekends, who enjoy walks and bicycle paths, and other recreational activities such as fishing and camping. These activities generate income and employments for ejidatarios, their families and community members. It is important to emphasize that all decisions concerning the park are taken in ejidatarios' assembly and there is an equitative sharing of benefits among all ejidatarios. A commission dedicated to the park's management is also elected in assembly.

San NicolásTotolapanejidatarios live form a variety of activities, which include farming for Mexico City market and urban employments, being the park only a part of their total income. For Miranda (2013) these variety of activities show that these ejidatarios move in a certain kind of armony between tradition and modernity. Specifically concerning tourism, they show how their so called traditional knowledge has been useful to them in order to manage their forest and the park. This knowledge, both ancestral and modern, has allowed them to use Nature without destroying it, and obtain a reasonable income.This knowledge concerns aspects like forest management, wild animal life, cosmologic and symbolic elements related to Nature, and it has given ejidatarios a good support to manage the park successfully. This knowledge had been part of ejidatarios life since many decades ago, as most of them knew how to manage their forest before the park project started. In spite of this, paradoxically there are some ejidatarios who despise their own "traditional" knowledge, and would prefer an entrepreneurial management of their forest resource, rather the communitarian approach that dominates the park today. The latter is expressed, for example, in the low access rates for families who visit the park during weekends. This contradiction between profit or ecological community service view is always present and generates harsh debates in the assembly.

This means that conflicts are not absent, as the park is working since 1996, and as it has been successful, there are groups in the ejido who dispute its management. It is important to mention that in this first stage, the founder group had the technical and scientific support of biologists from the Universidad AutónomaMetropolitana, a public university in Mexico City. This relation between ejidatariosand scientists shows how ancestral knowledge and modern science can collaborate in sustainable community based touristic projects. Through this dialogue with scientists and their own knowledge, the original eight ejidatarios who started the project are strongly convinced that the main objective is to contribute to sustainability more than economic benefits, but after them there have been other groups who have won assembly's elections and see the park only as an income source. This is one of the main risks for the park: that in order to obtain more money, ecologic objectives, such as sustainable management of the forest, can be neglected. Nevertheless, this has not yet happened.

Another important threat the park faces is urbanization, both for building luxury houses in the forest and for poor people who seek for a place to live and can invade the park. Selling land at increasing prices, in a big city such as Mexico City is an always present temptation. Ilegal wood extraction is also a permanent threat. Park's management and ejido are not extent of these temptations, and selling part of the woods can be seen as a better income alternative for some groups. Until now, it has succeeded a sense of belonging to their community and respecting Nature, which sees the forest as a common resource, but nothing can guarantee that in the future this will not change to a more individual way of conceiving land, that could resulton selling parts or the complete park.

In order to get more income of sustainable projects in the park, and in this way minimize individual selling temptations and reinforce common belonging sense, sustainable projects have been implemented, such as (Miranda, 2011): 
1. Vegetables greenhouse

2. Foresttreesbreeding

3. Organic worm fertilizer production

4. Christmas trees' production

5. Educational farm for school's visitors

6. Mexicanfood restaurant

7. Artcraftsproductionrecyclingwaste

8. Puppets theater, with environmental education contents

9. Educational vegetable production for children

10. Well water production

11. Agriculture museum

We think that through their park management in the last years, Totolapanejidatarios are a vivid example of how commons management can achieve sustainability's goals, deciding together and succeeding with reasonable incomes. They do this in a way that expresses a good common resource management in Ostrom's sense, being able to apply their own collective rules and knowledge. By conserving their forest, they also give valuable environmental services to a big polluted city, whose presence means powerful threats to the park's sustainability.

\section{Ecotouristic Cooperative Project in La Escobilla, OAXaCa}

Our second community based ecotouristic experience takes place in La Escobilla, a beach in Oaxaca southern Mexican state (Arellano, 2009). It shows how collective processes of men and women, fishers and peasants of a multi-racial group have driven to a sustainable ecotouristic project that involves sea turtle conservation. The main attractive of the project is Golfina turtle nesting on the beach, exploiting in a sustainable way this natural resource. La Escobilla people offer guided paths to see turtles' nesting. Other attractives are a beautiful tropical coast landscape, with boat rides and bird watching in some seasons, as marsh and lagoons are part of the preserved ecosystem. Besides, regional sea food is served in the project's restaurant, managed by community women. As Arellano (2014) research found, peasant-fishers identity in this human diverse group has been essential for them in order to reach success in their cooperative ecotouristic project.

Among the facts that made possible this project we can mention that this is the most important Golfina turtle nesting beach. Due to conservation policy and extinction risk of this specie, the Mexican Center of the Turtle conservation was built in the place in 1991.

In the sixties and seventies, many turtle meat and eggs' traders have made contracts with La Escobilla people to exploit without limits this resource, andthis lead Golfina turtle near to extinction. When conservation center began, its relation with La Escobilla people became difficult, as scientists of the center considered local inhabitants as turtle predators. In spite of this, some of these scientists suggested the community to start an ecotouristic project, so they could have incomes form the turtle nesting without predating the specie. As in TotolapanEcoturisticEjidal Park, herewe can find a dialogue between local inhabitants "traditional" knowledge about sea turtle and science, in order to achieve a sustainable project, which could both give reasonable profits to La Escobilla people and preserve turtles.

Another aspect is regional context, as in the seventies big touristic projects began in Oaxca's beatiful beaches, mainly in nearby Huatulco Bays, so an increasing number of tourists visit the region. Other face of this tourist development is a non-controlled and predatory growing of big hotels and massive tourism, competing with advantage with local ecoturistic projects such as La Escobilla, which can result on natural resources destruction. Besides, this kind of development has not meant better life conditions for local people, as this coast region shows high marginality conditions, even for Oaxaca, one of the poorest states of Mexico. It is also inhabited by a great diversity of indigenous people.

La Escobilla was founded by two families in 1930 and it was isolated. When the first path to Puerto Ángel, a nearby small port, was built, more families went to live there. In the seventies of XX Century a coast highway was built, and this meant for La Escobilla a population increase. A great hurricane, 
Paulina, happened in 1997 and most of the community's houses, the first ecotouristic project buildings, trees and anestuary were destroyed. People had to leave the community for some time. Later the houses were rebuilt and people came back.

La Escobilla people were dedicated to three main activities: fishery, agriculture and turtle's egg collection. The community has access to the main nesting beach of Golfina turtle, so both turtle and eggs are essential for the community's identity and history. People's memory registers that the first turtle's arrivals happened in the fifties in their beach. This meant that many people from other places came to collect eggs, and the government placed a military camp there in order to stop overexploitation, but it continued, so the Navy Minister intervened and promoted fishery's cooperatives. These cooperatives continued over-exploiting the natural resource, so the navy Minister placed a permanent camp in the beach. The latter means that for La Escobilla people eggs turtle as a profitable resource generated the appearance of new social actors: eggs traders who promoted overexploitation and the army, the navy and scientists interested in conservation.

A destructive trade of turtle's eggs was present since the sixties. Traders payed very low prices for the eggs and local people had not enough economic resources to pay bribes to authorities to allow the illegal trade, as traders did.This kind of trade, which implied that turtle's egg became a commodity and drove Golfina turtle near to extinction, meant for La Escobilla people that they were dominated by a market both of eggs and labor, where they were exploited and depend of such income. Besides, they were labeled as environmental predators, and in some cases were even sued because of these, while big traders remained untouched. The specie's conservation did not appear in any government environmental policy in these years.

This was the situation until the nineties, when things happened that changed La Escobilla people's way of life. On the one hand there appeared tourism and migration, and on the other Mexican Center of the Turtle and a Turtle Museum were founded in Mazunte, very close to La Escobilla. Besides, in La Escobilla a turtle research camp started, in the same place of the Navy Minister camp. This meant a change in State policies toward the place, where turtle's conservation goals were above community's needs. So, La Escobilla people have been always in a second place concerning turtles and eggs, both for illegal trade and conservation. Their territory has been always managed by external actors interested in the turtle and its eggs. This made a very difficult scenario for them to develop their own sustainable initiatives. In this sense, we could say that turtles and their eggs as a common were built by the community, they were not "given" by Nature.

Within these conditions, La Escobillaecotouristic cooperative began in 1999, as a result of both government institutions and community to seek for alternative economic activities, which could generate incomes for people without exploiting turtle's eggs, after destruction of the first buildings by Paulina hurricane in 1997. A real commons management started in 2004 by a group of the community, and in 1999-2005 period many conflicts arise.

It was not ecological consciousness who lead community people to start an ecotouristic cooperative, but their poverty conditions when turtle eggs exploitation was forbidden by Mexican Center of Turtle Conservation. In fact, the word "ecotourism" was rare to them, but their tenacity to endure difficulties and improve their income with their project was what led them to the success they have today. The first cooperative had 97 members, all the adult people of the community, but things did not work at first, they could not make any progress and in 2003 this first cooperative was disintegrated. Of the 97 original members only 12 remained, the first president resigned and a small 12 people group decided to try again, as they had already built the first restaurant. They made an assembly with the 97 original members, and 50 decided to leave, so the cooperative started with 47.

As Arellano (2014) states, this was the first time that local actors decided to generate their own project, without external interventions. Later, when it was necessary to give some money for the cooperative legal issues, more people left and only 28 remained.

One of the difficulties was the diverse origin of La Escobilla's inhabitants, as there are afrodescendents, zapoteco natives and mixed people, and some of themwanted to continue selling turtle egg and meat without any conservancy consideration. In fact, after the mentioned assembly to start again the cooperative, they could start their restaurant in April 2004, women participation was 
essential to this achievement, but the group interested in continuing with eggs' sellingset on fire this first restaurant, finished by the cooperative group in 2005. The latter did not surrender, rebuilt their restaurant with collective work (in Oaxaca it is named tequio) and the National Park of Chacahua lagoon helped them with funds. They finished their restaurant's rebuilding in 2006, started a tree's breeding project and now they have also some bungalows for tourists to stay, which were made with the National Indigenous People Comission support in 2006-2007.

Their relation with the turtle meat and egg sellers has become less violent and the group who wanted to continue selling eggs and meat is weaker now, after the ecotourist project has succeeded. Their relation with Mexican turtle Center has improved, and now some tourists are sent to eat at the restaurant and lodge in the bungalows. They also offer boat excursions to the estuary left by Paulina hurricane.

The process has meant for the cooperative members to re-signify their territory and resources, and to develop capacities in order to manage their project in a sustainable way. The experience shows that there is not any a priori methodology to implement sustainable rural projects that can alleviate poverty. In La Escobilla, the first actions of the Mexican Center of the Turtle were rejected by the community, as they implied only meat and egg's exploitation prohibition. It was in a harsh dialog for some years that the Center's scientist could convince a community group to start an ecotouristic project. This meant that they could have incomes and improve their poverty situation without destroying their natural resources and endanger turtles.

The resulting project was not what the Mexican Center of the Turtle staff had exactly proposed, as community participants made their own suggestions. This experience shows clearly how rural sustainable ecotouristic projects must be done form below, considering ideas and needs of local people. It shows too how conservation science can help in this kind of projects, when scientists and institutions are willing to hear what local people have to say. Otherwise, if external conservation institutions only impose and forbid resources' use to the locals, any project will fail.

\section{Our Conclusions: About the Possibility of Ecotouristic Sustainable Projects}

From the two experiences described, we are able to state that, first, although there is a stereotype of indigenous and local people as predatory of Nature and unable to manage their natural resources in a sustainable way, when certain conditions happen, local communities develop capabilities and use their own knowledge to use their natural resources without destroying them. In this way, although sometimes this kind of projects begin due to an economic need more than ecological consciousness concerns, as in La Escobilla Cooperative, both capabilities and environmental sensibilities can develop when the project succeeds.

Despite the existence of many threats to these projects, such as increasing urbanization in Totolapan Park, it is possible that local people can show a big city the importance of preserving forests that give necessary environmental service to the city. At the same time, projects such as this park mean that land owners can have incomes from preservation of Nature, rather than selling the land and increasing urban unsustainability and ecological damage. In La Escobilla case, threats come from illegal turtle eggs market, and people must have income from conservation if they are supposed to avoid this kind of predatory activities.

However, at present, these projects face typical accumulation by dispossession threats, such as predatory urbanization, illegal turtle eggs trade and massive tourism. This means that there is a pressure on the natural resources of local people, such as water, wild animals and biodiversity, managed as commons for centuries, to become private and individual property, to benefit tourist and urban "developers" in the best case, or illegal markets in the worst. What is making the difference in halting this type of projects and preserving their territory, culture, and natural resources are local organizations such as the TotolapanEcotouristicEjidal Park and La EscobillaEcotouristic Cooperative Project. Local people created their own organizations to achieve sustainability and have incomes respecting Nature. This does not mean they have completely succeeded or have no conflicts, but rather that they are alert and always ready to resist different threats in a permanently changing context.

The two experiences demonstrate howlocal people have been capable of engaging in dialogue, accepting external ideas and giving their own ones, in order to achieve sustainability without losing 
their identity, culture, and resources. This way, they provide a rich experience and knowledge about other forms of existing with Nature, rather than destroying it. No doubt these experiences contain valuable lessons against a predatory economic system that is leading world and Nature to selfdestruction.

\section{REFERENCES}

[1] Arellano, Jorge (2009). "El Camino al Ecoturismo de la Cooperativa Santuario de la Tortuga de La Escobilla (ANP). Oaxaca". Master Rural DevelopmentThesis, Universidad Autónoma Metropolitana. Mexico

[2] Arellano, Jorge (2014). "De actor a sujeto en el camino al ecoturismo. La Cooperativa Santuario de la Tortuga de La Escobilla, Oaxaca", in Mundos Rurales No.6. Recursos naturales y conflictos socioambientales. Cinco experiencias de los actores sociales rurales. Ed. Universidad Autónoma Metropolitana-Xochimilco. Mexico, pp. 205-254

[3] Bartra, Armando (2015). Con los pies en la tierra. Despojo y resistencia en los territorios. In:Bartra, Armando, Carlos Walter Porto-Gonçalves and MilsonBetancourt.Se hace terruño al andar. Las luchas en defensa del territorio. Ed. Universidad Autónoma Metropolitana-Xochimilco, Ithaca. Mexico. In press

[4] Boege, Eckart (2008). El patrimonio biocultural de los pueblos indígenas de México. Hacia la conservación insitu de la biodiversidad y agrodiversidad en los territorios indígena. Editorial Instituto Nacional de Antropología e Historia. Comisión Nacional para el Desarrollo de los Pueblos Indígenas.Mexico

[5] Escobar, Arturo (1995). Encountering Development. The Making and Unmaking of the Third World. Princeton, NJ, USA: Princeton University Press Princeton Studies in Culture/History

[6] Harvey, David (2004). "The New Imperialism: accumulation by dispossession". Vol. 40. Socialist Register 2004: The New Imperial Challenge.http://socialistregister.com/index.php/srv/issue/view/441\# VJG2dyu G9u4 (Accessed December 8th, 2014).]

[7] Leff, Enrique (2004). Racionalidad ambiental, la reapropiación social de la naturaleza. Siglo XXI Editores. Mexico

[8] Miranda, Gloria (2011). Contribuciones de las Comunidades Rurales a la Sustentabilidad. Parque Ejidal Ecoturístico San Nicolás Totolapan, Ciudad de México. Ed. Universidad de Guanajuato, CDI, Axolot México Sustentable. Mexico

[9] Miranda Gloria (2014). "El conocimiento tradicional en la gestión del ecoturismo comunitario sustentable. Renovadas miradas teóricas para involucrarse en la comunidad rural", in Mundos Rurales No.6. Recursos naturales y conflictos socioambientales. Cinco experiencias de los actores sociales rurales. Ed. Universidad Autónoma Metropolitana-Xochimilco. Mexico, pp.15-92

[10] O'Connor, James (2001). Causas naturales. Ensayos de marxismo ecológico. Siglo XXI Editores. México. Pp.191-212.

[11] Porto-Gonçalves, Carlos W. and Milson Betancourt (2015), "Encrucijada latinoamericana en Bolivia: el conflicto del TIPNIS y sus implicaciones civilizatorias". In: Bartra, Armando, Carlos Walter PortoGonçalves and Milson Betancourt. Se Hace Terruño al Andar: las Luchas en Defensa del Territorio. Ed. Universidad Autónoma Metropolitana-Ithaca. Mexico. In press.

[12] Ostrom, Elinor (1990), El gobierno de los bienes comunes. La evolución de las instituciones de acción colectiva. Editorial Fondo de Cultura Económica. Mexico

Citation: Gloria Miranda, Yolanda Massieu, Jorge Arellano. "Rural Tourism in Mexico: Two Community Based Sustainable Experiences". International Journal of Research in Tourism and Hospitality (IJRTH), vol 6, no. 3, 2020, pp. 23-32. doi: https://doi.org/10.20431/2455-0043.0603003.

Copyright: ( $) 2020$ Authors. This is an open-access article distributed under the terms of the Creative Commons Attribution License, which permits unrestricted use, distribution, and reproduction in any medium, provided the original author and source are credited. 